\title{
Marko Ampuja: \\ Theorizing Globalization. \\ A Critique of the Mediatization of Social Theory. \\ Leiden: Brill. 2012.
}

Nete Nørgaard Kristensen

MedieKultur 2013, 55, 105-108

Published by SMID | Society of Media researchers In Denmark | www.smid.dk

The online version of this text can be found open access at www.mediekultur.dk

Marko Ampuja's book Theorizing Globalization. A Critique of the Mediatization of Social Theory provides a critical perspective on globalization theory and especially what the author labels the media-centrism of this theoretical paradigm. Ampuja argues that the media-centrism of much globalization theory is closely linked to the fact that too much emphasis is put on the importance of media and communication technology. Or put differently; due to technological determinism. As a consequence, the arguments of a great deal of globalization theory lack historical reflection and attention to political and social realities as well as to the implicit connections between globalization theory and neoliberalist thinking.

The book includes six chapters, divided into four sections. After an introductory chapter, outlining the arguments of the book, the first section provides useful but also very critical introductions. First, chapter one introduces the academic literature and central theorists on the complex, multidimensional and widespread concept of globalization, the historical development of globalization theory, and its skeptical voices. Summing up, critically but not surprisingly, the author concludes that time-space relations or "interconnectedness" seem to be the key feature characterizing much of globalization theory. On this basis, the second chapter turns to the relations between media theory and globalization theory, arguing that their boundaries are increasingly blurring. This line of reasoning is developed by briefly outlining well-known arguments from the political economy of the media, cultural studies, and medium theory. These two introductory chapters demonstrate 
the author's extensive overview and detailed knowledge of the vast scholarly literature on globalization, on selected but central media theoretical traditions, and especially on the ways in which the latter (central media theoretical traditions) have informed or been taken up by the former (globalization literature) and, thus, how their arguments interconnect. In other words, the first section provides the reader with a condensed but useful outline of important theoretical perspectives upon which the author's critique in the remainder of the book rests. For the same reason, the chapters also display an inclination to first and foremost pinpoint the weaknesses of the arguments and positions of especially the existing literature on globalization theory. This is, of course, in line with the aim of the book, but it does make the discussions, particularly in chapter one, appear somewhat one-sided, because mainly shortcomings are highlighted.

In the following two sections, the author discusses the contributions of four social theorists in more detail (Manuel Castells, Scott Lash, John Tomlinson, and Arjun Appadurai) in order to establish and develop his argument on the media-centrism of globalization theory. Ampuja has chosen to focus on these specific theorists because he finds that they:

... represent the central problematic of globalization theory, namely, the argument that the key to understanding social and cultural change today is to examine how the experience of time and space has been altered and how media and communications have contributed to this alteration (p. 10).

Chapters three and four lay out and analyze the main works, concepts, and arguments of Castells and Lash respectively, critically emphazising how they first and foremost offer media-technological rationales for globalization. Based on a similar structure, chapter five outlines the work of Tomlinson and Appadurai, in one chapter, and their perspectives on cultural globalization, particularly criticizing "their overconfidence in the emancipatory nature of deterritorialization or hybridization (...)" (p. 306). The strength of parts two and three is the very detailed introductions to the specific works of the four theorists as well as the close readings of their multifaceted arguments, how the arguments of each theorist have developed throughout their work, and how the arguments of the four theorists relate to and differ from each other. Even though these two parts also display an openly critical perspective, mainly looking for the, according to the author, flaws of the theoretical positions, the chapters appear much richer in their reading and more nuanced compared to the introductory chapters.

In the concluding section (chapter 6), Ampuja argues that the media-centrism of much globalization theory since the $1990 \mathrm{~s}$ is closely linked to the neoliberal thinking that has characterized the same period. His criticism is that this linkage is neither acknowledged nor analyzed by globalization theorists, among others those scrutinized in the preceding chapters, seeing this as a sign of the hegemony of neoliberalism. In continuation he asserts that social theory has been "mediatized" due to the heavy focus on media and communication as drivers of social changes, neglecting political, social or economic perspectives (e.g., p. 
356). Thus the concluding chapter draws on the concept "mediatization", as also stipulated by the subtitle of the book. A theoretical concept, which itself has become ubiquitous in media research in recent years, and which, by some media scholars, has been compared to or viewed as a meta-process (Krotz, 2009) or a modernization process (Hjarvard, 2013) in line with globalization. However, in Ampuja's book "mediatization" serves first and foremost as a rhetorical tool, or as a synonym for the media-centrism that the author finds characteristic of much globalization theory. Even though parts of the recently developed arguments of mediatization theory may, like globalization theory, be criticised for technological determinism, for putting too much emphasis on the importance of the media in cultural and social change, or for being to comprehensive (e.g., Couldry, 2008), Ampuja does not pay detailed attention to the arguments of this media theoretical framework, the work of important mediatization theorists, or the connections between mediatization theory and globalization theory. Two obvious reasons for this are 1) the fact that mediatization is only a more recently developed theoretical concept or outline for understanding contemporary societal and cultural changes, whereas globalization theory has a history of more than twenty years - even though the latter is well-known by the former; 2) and the fact that Ampuja's work first and foremost takes its point of departure in social theory and not in media and communication research. Nonetheless, by including a more detailed discussion of mediatization theory, Ampuja's book would not only have been an interesting, critical contribution to the scholarly discussion of globalization, but also to one of the dominating theoretical agendas in contemporary media and communication research.

In conclusion, Theorizing Globalization. A Critique of the Mediatization of Social Theory provides a noteworthy reading of parts of the extensive scholarly literature on globalization, including useful presentations and critical discussions of key theorists and their theoretical standpoints during especially the last 20-25 years of academic discussion of globalization, and particularly of the role and importance ascribed to media and communication in these discussions of social transformation processes. Even though the aim of the book is precisely to provide an explicitly critical contribution and point to other driving forces than media and communication, one may criticize the book for distancing itself from the media and communication perspective to such an extent that it does not seem to recognize media and communication technology as, if not the key factor, then one important factor of recent societal changes - in line and intertwined with political, economic, technological, and social forces. Despite this critical, and to some extend one-sided approach, the book provides useful introductions and discussions for media scholars and media students, precisely due to its critical stance and not least due to its very close readings and discussions, presented in a clear and informative manner, of some of the social theorists who have profoundly provided a theoretical background for recent media and communication research. 
Book review: Theorizing Globalization

\section{References}

Couldry, N. (2008). Mediatization or mediation? Alternative understandings of the emergent space of digital storytelling. New Media \& Society, 10(3), 373-391.

Hjarvard, S. (2013). The mediatization of culture and society. Oxon: Routledge.

Krotz, F. (2009). Mediatization: A concept with which to grasp media and societal Change", in Knut Lundby (ed.), Mediatization: Concepts, changes, consequences, pp. 21-40. NY: Peter Lang.

Nete Nørgaard Kristensen

Associate Professor, PhD

Department of Media, Cognition and Communication

University of Copenhagen, Denmark

netenk@hum.ku.dk 